\title{
Pola Komunikasi Guru Dalam Pembelajaran Anak Usia
}

\section{Dini Melalui Bermain}

\author{
Received: 11 April 2021 \\ Revised : 02 Juni 2021 \\ Accepted : 16 Juni 2021 \\ Elya Siska Anggraini \\ Prodi PG PAUD FIP UNIMED \\ Jln. Williem Iskandar Pasar V Medan Estate, Medan, Sumatera Utara, 20371 \\ Email : elyasiskaanggraini@unimed.ac.id
}

\begin{abstract}
Abstrak : Artikel ini bertujuan untuk mengetahui pola komunikasi guru dalam pembelajaran anak usia dini, sehingga adanya upaya seorang guru dalam mengembangkan komunikasi efektif dalam pendidikan anak usia dini melalui pola komunikasi. Teknik pengumpulan data melalui analisis deskriptif. Pola komunikasi dalam belajar mengajar adalah adanya sebuah kegiatan yang dilakukan antara guru dan peserta didik agar tercapainya tujuan dengan adanya perubahan tingkah laku, meningkatnya aspek perkembangan anak, pemahaman, keterampilan, dan sikap. Pola komunikasi guru yaitu: (1) Pola komunikasi primer, (2) pola komunikasi media (mainan), (3) Pola komunikasi dialog (4) Pola komunikasi perhatian, (5) Pola komunikasi / stimulasi. Pada anak usia dini, bermain dapat memberikan banyak manfaat terhadap perkembangannya. Adapun manfaat bermain dapat mengembangkan aspek moral, motorik, kognitif, bahasa, serta perkembangan sosial anak.
\end{abstract}

Kata kunci : Pola Komunikasi, Komunikasi Guru, Bermain, Anak Usia Dini.

\section{PENDAHULUAN}

Perkembangan pada Pendidikan Anak Usia Dini (PAUD) terdiri dari beberapa aspek yang harus dikembangkan. Perkembangan ini akan menjadi dasar bagi perkembangan anak selanjutnya. Salah satunya adalah aspek perkembangan bahasa. Perkembangan bahasa tergantung pada kematangan sel korteks, dukungan lingkungan, dan keterdidikan lingkungan. Beberapa hal yang penting dalam perkembangan bahasa adalah perkembangan persepsi, pengertian, adaptasi, imitasi, dan ekspresi (Itadz, 2008:7).

Perkembangan bahasa adalah kemampuan berbahasa lisan pada anak yang berkembang karena terjadi kematangan dari organ-organ bicara juga karena lingkungan ikut membantu mengembangkannya (Gunarsa, 2008). Perkembangan bahasa anak meliputi perkembangan fonologis (yakni mengenal dan memproduksi suara), perkembangan kosakata, perkembangan sematik atau makna kata, perkembangan sintaksis atau penyusunan kalimat, dan perkembangan pragmatik atau penggunaan bahasa untuk keperluan komunikasi (sesuai dengan norma konvensi). Pada anak usia TK atau pra-sekolah, perkembangan fonologis belum sempurna, namun hampir semua yang dikatakannya dapat dimengerti. Selain itu, IQ anak sudah relatif stabil (Itadz, 2008:7).

Kemampuan Berbahasa merupakan perkembangan bahasa yang perlu dikembangkan pada dunia anak. Kemampuan berbahasa akan terus menerus dikembangkan agar anak mampu berinteraksi dengan masyarakat. Anak dapat menyampaikan apa yang dipikirkannya, mampu berinteraksi dengan masyarakat, menyampaikan ekspresi dan menyatakan peraaan kepada orang lain. Kemampuan berbahasa anak dimulai melalui lingkungan sekitar anak hidup. Oleh karena itu, bahasa yang dikenal anak adalah bahasa Ibu. Anak belajar pertama kali dari keluarga, lalu lingkungan masyarakat. Sehingga bahasa yang pertama dikenal anak adalah bahasa yang ada di keluarga dan masyarakat. Kemampuan berbahasa pada anak usia 
dini dapat dilihat dari pola komunikasi anak sehari-hari. Komunikasi anak dimulai dari keluarga, terutama dari orangtua.

Komunikasi adalah proses penyampaian suatu pernyataan oleh seseorang kepada orang lain (Djamarah, 2004:11). Komunikasi sebagai media untuk anak mengungkapkan perasaan, keinginan maupun sikap sosialisasi anak. Komunikasi awal anak sudah dimulai sejak didalam kandungan, yaitu komunikasi dengan ibunya. Komunikasi dapat dibedakan menjadi dua, yaitu komunikasi verbal dan komunikasi non verbal. Komunikasi verbal berupa kata-kata, kalimat, percakapan; sedangkan komunikasi nonverbal berupa bahasa tubuh seseorang. Pola komunikasi yang dibangun akan mempengaruhi perkembangan jiwa dan pola pikir anak, serta mempengaruhi kondisi kejiwaan anak secara langsung dan tidak langsung. Komunikasi yang diharapkan adalah komunikasi yang efektif dapat menimbulkan pengertian, kesenangan, pengaruh pada sikap, hubungan yang makin baik dan tindakan.

Lingkungan terdiri dari lingkungan keluarga dan lingkungan masyarakat. Lingkungan keluarga merupakan tempat pertama kali anak belajar dan mengenal tentang nilai-nilai kehidupan. Pada saat anak pertama kali lahir di dunia, anak sudah mulai belajar dan mengenal tentang lingkungannya. Orangtua merupakan tokoh utama dalam pembentukan pribadi, model yang dijadikan contoh anak dalam berperilaku serta sosok yang berpengaruh dalam perkembangan anak. Sedangkan lingkungan masyarakat merupakan tempat anak belajar bersosialisasi dan mengenal tentang norma-norma sosial. Lingkungan masyarakat seperti sekolah juga berpengaruh terhadap perkembangan anak.

Kemampuan berbahasa anak berbeda-beda. Terdapat anak yang memiliki kemampuan berbahasa sudah baik dan ada juga yang masih kurang. Ada anak yang terus berusaha mengolah kata, mengungkapkan keinginan, dan mengekspresikan ide. Namun ada juga anak yang pendiam, kurang dalam mengungkapkan keinginan dan mengekspresikan ide kepada guru atau teman-temannya. Anak memiliki jenis pola komunikasi dengan orang tua dalam kegiatan sehari-hari yang berbeda-beda, dengan kesibukan orang tua dan pola komunikasi guru yang berbeda-beda sehingga berpengaruh terhadap intensitas mereka dalam berkomunikasi, bertukar cerita atau pengalaman dan mengekspresikan ide.

Bermain merupakan cara yang paling baik untuk mengembangkan kemampuan anak. Selain itu, bermain manjadi cara yang baik bagi anak dalam memahami diri, orang lain, dan lingkungan. Pada saat bermain, anak-anak mengarahkan energi mereka untuk melakukan aktivitas yang mereka pilih sehingga aktivitas ini merangsang perkembangannya. Bagi anak, bermain membawa harapan tentang dunia yang memberikan kegembiraan dan memungkinkan anak berkhayal tentang sesuatu atau seseorang. Menurut Piaget, bermain adalah suatu kegiatan yang dilakukan berulang-ulang dan menimbulkan kesenangan atau kepuasan bagi diri seseorang. Menurut Parten, bermain adalah suatu kegiatan sebagai sarana bersosialisasi dan dapat memberikan kesempatan anak bereksplorasi, menemukan, mengekpresikan perasaan, berkreasi, dan belajar secara menyenangkan. Sedangkan menurut Docket dan Fleer, bermain merupakan kebutuhan bagi anak, karena melalui bermain anak akan memperoleh pengetahuan yang dapat mengembangkan kemampuan dirinya. Beberapa pendapat tentang pengertian bermain di atas, dapat dipahami bahwa bermain adalah suatu upaya untuk memperoleh kesenangan dan kepuasan jiwa dari setiap aktivitas yang dilakukan, baik menggunakan alat permainan maupun tidak. Oleh karena itu, perlu diterapkan pola komunikasi guru yang efektif untuk merangsang pertumbuhan dan perkembangan anak usia dini. 


\section{KAJIAN TEORI}

\section{Bermain Pada Anak Usia Dini}

Bermain merupakan kegiatan yang sangat penting bagi pertumbuhan dan perkembangan anak. Bermain harus dilakukan atas inisiatif anak dan atas keputusan anak itu sendiri, agar anak berminat untuk melakukan kegiatan guru harus mempersiapkan permainan apa yang akan dimainkan, dan alat permainan edukatif untuk anak. Bermain peran bisa dijadikan salah satu cara untuk menciptakan kegiatan yang bisa menarik perhatian anak agar mau melakukan kegiatan didalam atau diluar kelas. Untuk mengaplikasikan kegiatan bermain peran anak maka perlu dipahami tentang pengertian bermain, jenis bermain, bermain peran, jenis bermain peran dan fungsi bermain bagi anak usia dini.

Teori Singer oleh Jerome Singer dalam (Mutiah, 2012 : 107) mengatakan bahwa "bermain memberikan suatu cara bagi anak untuk masuknya perangsangan (stimulasi), baik dari luar maupun dari dalam yaitu aktivitas otak yang konstan memainkan kembali dan merekam pengalaman". Menurut (Mutiah, 2012 : 92) "Bermain bagi anak adalah eksplorasi, eksperimen, peniruan (imitation), dan penyesuaian (adaptasi)". Anakanak belajar melalui permainan mereka, pengalaman bermain yang menyenangkan dengan bahan, benda, teman sebaya dan dukungan orang dewasa membantu anak-anak berkembang secara optimal.

\section{Fungsi Bermain}

Permainan mempunyai arti sebagai sarana mensosialisasikan diri anak, dengan bermain keterampilan berbicara anak dapat dikembangkan. Pada masa usia dini, anak mulai berfikir simbolis dan menggunakan kata-kata untuk untuk mengganti gambar dan gerakan tubuh. Anak mulai menggunakan kata-kata untuk menyampaikan keinginannya, membagi rasa dan berinteraksi sosial. "permainan digunakan sebagai sarana membawa anak kealam masyarakat, permainan sebagai sarana untuk mengukur kemampuan dan potensi diri anak" (Mutiah, 2012 : 113). Dalam situasi bermain anak akan dapat menunjukkan bakat, fantasi, dan minatnya. Saat bermain anak akan menghayati berbagai emosi yang mungkin muncul seperti rasa senang, gembira, tegang, kepuasan dan rasa kecewa. Dengan bermain anak bisa memngembangkan keterampilan berbicara dengan menyimak aturan-aturan yang berlaku pada saat kegiatan bermain dilakukan, mengenal kata-kata dan menambah banyak kosa kata yang anak miliki. Dan tentunya, dengan bermain anak belajar banyak hal dan dengan bermain seluruh aspek perkembangan anak dapat terstimulus. Sedangkan menurut Stone dalam (Yuliani dan Bambang, 2013 : 36) mengatakan bahwa "kegiatan bermain dapat mengembangkan berbagai potensi pada anak, tidak saja pada potensi fisik tetapi juga pada perkembangan kognitif, bahasa, sosial, emosi, kreativitas, dan pada akhirnya prestasi akademik".

\section{Jenis-jenis bermain}

Diungkapkan oleh Smilansky dalam Fauziah (2010:111) terdapat tiga jenis bermain, yaitu 1) bermain simbolik, 2) bermain konstruktif, dan 3) bermain drama.

1) Bermain simbolik. Bermain dengan menghadirkan sesuatu sebagai simbol, telah dimulai sejak anak berusia dua tahun dan terus berlangsung dalam 21 berbagai bentuk hingga mereka dewasa. Bermain simbolik terkait dengan permainan konstruktivif dan bermain drama.

2) Bermain konstruktif. Bermain konstruktif menggunakan materi atau objek terkait fungsi atau lebih canggih lagi dapat terkait dengan simbol. Anak menciptakan sendiri atau membangun sendiri materi secara konkrit dan menghadirkannya sebagai objek. Intinya dalam main pembangunan bukan hanya karya yang diperhatikan tetapi yang lebih penting adalah membangun gagasan dan cara berpikir anak itu sendiri. Contohnya adalah bermain menyusun balok dan benda cair. 
3) Bermain drama. Bermain drama anak menciptakan sendiri tokoh imajinasi yang mereka inginkan. Mereka bermain dengan gambar,bereksperimen dengan situasisituasi yang diinginkan. Jika ada dua anak atau lebih terlibat dalam permainan itu, maka akan terjadilah permainan sosiodrama. Misalnya anak akan bermain dokterdokteran, ibuibuan, masak-masakan atau bermain dengan berbagai tema yang mereka pilih melalui rundingan (negosiasi) bersama teman. Ketika mereka bermain sendiri, mereka akan berbicara sendiri, sesuai dengan fantasi mereka sebagai anak. Begitulah cara mereka memahami dunia mereka sebagai anak, untuk membangun bahasa, dan kecakapan sosial lainnya.

\section{Pengertian Komunikasi}

Komunikasi berasal dari bahasa latin "communis" atau "commun" dalam bahasa Inggris yang berarti sama. Berkomunikasi berarti sedang berusaha untuk mencapai kesamaan makna, commonness. Melalui komunikasi kita mencoba berbagai informasi, gagasan atau sikap dengan partisipan lainnya. Kendala utama dalam berkomunikasi adalah sering terjadi kesalahpahaman makna yang berbeda terhadap lambang yang sama. Oleh karena itu, komunikasi seharusnya dipertimbangkan sebagai aktivitas dimana tidak ada tindakan atau ungkapan yang diberi makna secara penuh, kecuali jika diidentifikasikan oleh partisipan komunikasi yang terlibat. Pengertian komunikasi secara umum adalah proses penyampaian suatu pernyataan yang dilakukan seseorang kepada orang lain sebagai konsekuensi dari hubungan sosial.

Ada banyak pendapat mengenai pengertian komunikasi dari para komunikolog, diantaranya:

a. Menurut Onong Uchjana, yang mengatakan bahwa istilah komunikasi berasal dari perkataan bahasa Inggris communication yang bersumber dari bahasa Latin communication yang berarti pemberitahuan atau pertukaran pikiran. Makna hakiki dari communication ini adalah communis yang berarti sama atau kesamaan arti

b. Menurut Deddy Mulyana, komunikasi adalah proses berbagi makna melalui perilaku verbal dan non verbal

c. Melalui Harold Laswell yang dikutip Deddy Mulyana, cara yang baik untuk menggambarkan komunikasi adalah dengan menjawab pertanyaan-pertanyaan berikut: Who Says What In Which Channel To Whom With What Effect? Atau Siapa Mengatakan Apa Dengan Saluran Apa Kepada Siapa Dengan Pengaruh Bagaimana?

\section{Unsur - Unsur Komunikasi}

Setiap proses tentu terdapat unsur-unsur di dalamnya yang mendukung proses itu sehingga dapat berlangsung dan membentuk proses. Hal tersebut tak terkecuali dengan proses komunikasi, dimana melibatkan unsur-unsur sebagai berikut:

a. Sender, komunikator yang menyampaikan pesan kepada seseorang atau sejumlah orang.

b. Encoding, penyandian yaitu proses pengalihan fikiran ke dalam bentuk lambang.

c. Message, pesan yang merupakan seperangkat lambang bermakna yang disampaikan oleh komunikator.

d. Media, saluran komunikasi tempat berlalunya pesan dari komunikator kepada komunikan.

e. Decoding, pengawasandian yaitu proses di mana komunikasi menetapkan makna pada lambang yang disampaikan oleh komunikator kepadanya.

f. Receiver, komunikan yang menerima pesan dari komunikator.

g. Response, tanggapan, seperangkat reaksi pada komunikan setelah diterpa pesan.

h. Feedback, umpan balik yaitu tanggapan komunikan apabila tersampaikan atau disampaikan oleh komunikator kepadanya. 
i. Noise, gangguan tak terencana yang terjadi dalam proses komunikasi sebagai akibat diterimanya pesan lain oleh komunikan yang berbeda dengan pesan yang disampaikan oleh komunikator kepadanya.

\section{Proses Komunikasi}

Proses komunikasi terbagi menjadi dua tahap, yakni secara primer dan secara sekunder.

a. Proses Komunikasi secara primer

Proses komunikasi secara primer adalah proses penyampaian pikiran atau perasaan seseorang kepada orang lain dengan menggunakan lambang (simbol) sebagai media. Lambang sebagai media primer dalam proses komunikasi adalah bahasa, isyarat, gambar, warna, dan lain sebagainya yang secara langsung mampu "menerjemahkan" pikiran dan atau perasaan komunikator kepada komunikan.

b. Proses Komunikasi secara sekunder

Proses komunikasi secara sekunder adalah proses penyampaian pesan oleh seseorang kepada orang lain dengan menggunakan alat atau sarana sebagai media kedua setelah memakai lambang sebagai media pertama. Seorang komunikator menggunakan media kedua dalam melancarkan komunikasinya karena komunikan sebagai sasarannya berada di tempat yang relatif jauh atau jumlahnya sangat banyak. Surat, telepon, surat kabar, majalah, radio, televisi, film, dan banyak lagi adalah media kedua yang sering digunakan dalam komunikasi.

\section{Komunikasi Verbal dan Nonverbal}

Komunikasi digunakan untuk menciptakan atau meningkatkan aktivitas hubungan antara manusia atau kelompok.

a. Komunikasi Verbal

Komunikasi verbal atau sering disebut pesan verbal pada dasarnya merupakan pesan yang berupa kata atau kata-kata yang bermakna bagi individu atau kelompok (masyarakat). Kata-kata itu sering disebut dengan bahasa. Contoh, ketika seseorang merasa senang atau puas maka akan mengatakan "terima kasih", "wah ini baru pas". Maka dengan demikian dapat ditegaskan bahwa komunikasi verbal merupakan komunikasi yang menggunakan kata-kata dalam penyampaian pesan, baik yang berhubungan dnegan gagasan, perasaan, atau maksud tertentu dari komunikator kepada komunikan.

b. Komunikasi Nonverbal

Komunikasi nonverbal atau pesan nonverbal merupakan salah satu bentuk komunikasi yang sering digunakan dalam presentasi, dimana penyampaiannya bukan dengan katakata ataupun suara tetapi melalui gerakan-gerakan anggota tubuh yang sering dikenal dengan istilah bahasa isyarat atau body language. Pesan nonverbal memiliki pengaruh yang sangat kuat dalam proses komunikasi.

\section{Bentuk-Bentuk Komunikasi}

a. Komunikasi Intrapersonal (Intrapersonal Communication) Komunikasi intrapersonal pada dasarnya komunikasi yang berlangsung dengan dirinya sendiri. Dalam kehidupan sehari-hari sebenarnya kita sering melakukan bentuk komunikasi ini. Contohnya, ketika berada di kantor, perut terasa lapar yang sangat dan ingin memutuskan untuk makan atau tidak. Situasi seperti ini sebenarnya kita sedang berbicara dengan diri kita sendiri untuk memutuskan makan sekarang atau nanti, dengan lauk apa, belinya di mana, dan sebagainya.

b. Komunikasi Interpersonal (Interpersonal Communication) Komunikasi interpersonal pada dasarnya merupakan proses komunikasi yang dilakukan dua orang atau lebih secara langsung (tatap muka) dan dialogis. Karena bersifat langsung dan tatap muka dalam komunikasi interpersonal respon atau tanggapan dapat dilakukan pada saat itu juga. Dengan adanya respon yang langsung dan dapat diamati langsung oleh 
komunikator, maka komunikator dapat dengan mudah untuk mengetahui situasi komunikasi yang sedang berjalan. Oleh karena itu, komunikator dapat dengan segera mengubah strategi komunikasi jika diperlukan. Contonya, ketika lawan bicara kurang berminat saat berkomunikasi, maka komunikator dapat dengan segera mengubah gaya, intonasi, kontak dengan komunikan, dan sebagainya.

c. Komunikasi Kelompok (Group Communication) Komunikasi kelompok pada dasarnya proses komunikasi yang dilakukan oleh sejumlah orang dengan norma dan peran yang ditentukan oleh kelompok itu. Sejumlah orang yang dimaksud adalah dua orang atau lebih. Norma pada dasarnya merupakan aturan, tatanan, atau kesepakatan yang dibuat oleh anggota dan berlaku dalam kelompok itu, misalnya perilaku apa saja yang boleh dan baik dilakukan dan yang yang tidak baik dilakukan dalam kelompok itu.

d. Komunikasi Massa (Mass Communication) Komunikasi massa pada dasarnya merupakan proses komunikasi yang ditujukan kepada massa (khalayak-umum) dengan menggunakan sarana media massa. Komunikasi massa mempunyai ciri-ciri khususnya yang disebabkanoleh sifat-sifat komponennya. Ciri-cirinya yaitu komunikasi massa berlangsung satu arah, komunikator pada komunikasi massa melembaga, pesan pada komunikasi massa bersifat umum, media komunikasi massa menimbulkan keserempakan, komunikan komunikasi massa bersifat heterogen.

\section{Pola Komunikasi}

Menurut Kamus Besar Bahasa Indonesia, pola berarti bentuk atau sistem12, sedangkan dalam kamus istilah popular "pola" diartikan sebagai model, contoh, pedoman (rancangan). Pola dapat dikatakan juga dengan model, yaitu cara untuk menunjukkan sebuah objek yang mengandung kompleksitas proses di dalamnya dan hubungan antara unsur-unsur pendukungnya. Jadi komunikasi berarti penyampaian pesan dari komunikator (pemberi pesan) kepada komunikan (penerima pesan), sehingga pesan menjadi hal pokok dalam berkomunikasi karena bukan dinamakan komunikasi jika di dalamnya tidak terdapat pesan baik verbal maupun non verbal.

Menurut Stewart L. Tubbs dan Silva Moss, ciri-ciri komunikasi yang baik dan efektif paling tidak menimbulkan:15

a) Pengertian. Penerimaan yang cermat dari isi stimuli seperti apa yang dimaksud oleh komunikator.

b) Kesenangan. Menjadikan hubungan yang hangat dan akrab serta menyenangkan.

c) Mempengaruhi sikap. Dapat mengubah sikap orang lain sehingga bertindak sesuai dengan kehendak komunikator tanpa merasa terpaksa.

d) Hubungan sosial yang baik. Menumbuhkan dan mempertahankan hubungan yang memuaskan dengan orang lain dalam hal interaksi.

e) Tindakan. Membuat komunikan melakukan suatu tindakan yang sesuai dengan stimulasi.

Secara umum pola komunikasi dapat diartikan sebagai suatu model proses penyampaian informasi. Pola komunikasi identik dengan proses komunikasi karena pola komunikasi merupakan bagian dari proses komunikasi. Pola komunikasi dapat digambarkan sebagai berikut:

a) Pola Komunikasi Satu Arah

Komunikasi satu arah merupakan pola komunikasi yang menitikberatkan pada penyampaian informasi atau pesan dari komunikator ke komunikan tanpa adanya umpan balik (feedback). Contoh dari komunikasi satu arah adalah ceramah.

b) Pola Komunikasi Dua Arah

Komunikasi dua arah merupakan komunikasi tatap muka yang menunjukkan bahwa pihak komunikan dapat melakukan umpan balik (feedback) kepada komunikator 
dalam proses penyampaian pesan atau informasi sehingga terjadi interaksi antara komunikator dan komunikan.

c) Pola Komunikasi Multi Arah

Komunikasi banyak arah atau komunikasi sebagai transaksi. Komunikasi ini tidak hanya melibatkan interaksi yang dinamis antara komunikator dan komunikan tetapi juga melibatkan interaksi yang dinamis antara komunikan yang satu dan yang lainnya.

\section{Jenis-Jenis Komunikasi Guru dalam Pembelajaran di PAUD}

Pada kegiatan pembelajaran yang berlangsung di Taman Kanak-kanak biasanya ibu guru menggunakan jenis komunikasi verbal, yaitu berupa kata dalam berkomunikasi kepada anak. Seperti pendapat Muhammad (2009) bahwa jenis komunikasi terdiri dari dua, yaitu komunikasi verbal dan non verbal. Saat guru menyampaikan menjelaskan materi yang akan dipelajari pada hari tersebut dengan tema yang sudah ada, guru menjelaskan materi dengan menggunakan jenis komunikasi verbal. Penggunaan komunikasi verbal ini diharapkan anak-anak dapat mengerti penyampaian materi yang disampaikan oleh guru dan mampu untuk menggabungkan kemampuan kognitif, efektif, psikomotorik, bahasa, sosialemosional, dan spiritual (Ridho, Markhamah, \& Darsinah, 2015). Kegiatan komunikasi verbal terjadi pada saat guru sedang berinteraksi dengan anak-anak yaitu ketika guru sedang menerangkan materi pelajaran, adanya kegiatan bernyanyi, bermain, bercerita dan juga mengerjakan tugas di buku. Jenis komunikasi seperti ini juga terlihat dari cara guru menanggapi tingkah laku dan sikap anak-anak ketika diperintahkan untuk mengerjakan soal, jika ada anak yang tidak mau melaksanakan apa yang ibu guru perintahkan maka guru tersebut mencoba mendekati anak dengan cara mengajak bersama-sama mengerjakan tugas, kemudian guru memberikan nasehat atas perilaku anak. Pernyataan di atas diperkuat (Hardjana, 2003) komunikasi verbal adalah komunikasi yang menggunakan penggunaan kata, baik secara langsung maupun tidak langsung.

Komunikasi verbal merupakan komunikasi yang paling banyak digunakan oleh manusia. Melalui kata-kata seseorang dapat mengungkapkan sebuah perasaan, emosi, pemikiran, ide, atau maksud mereka, menyampaikan fakta, data, dan informasi serta menjelaskannya, dengan cara saling bertukar pikiran dan pemikiran, saling berdebat dan bertengkar. Komunikasi verbal yang dilakukan guru pada saat memberikan kegiatan pembelajaran pada anak didiknya dapat disimpulkan bahwa semua guru yang ada di kelas A menggunakan komunikasi verbal dalam berkomunikasi pada proses berinteraksi dengan anak didiknya. Komunikasi verbal dianggap paling berguna pada saat guru berinteraksi dengan anak secara langsung. Komunikasi non verbal ini juga digunakan oleh guru kelas A dalam berkomunikasi dengan anak-anak di dalam kelas. Komunikasi non verbal yang dilakukan guru kepada anak-anak dapat berupa intonasi suara pada saat guru berbicara, gerakan-gerakan tubuh pada saat menjelaskan materi dan ekspresi saat berkomunikasi pada anak-anak.

\section{METODOLOGI PENELITIAN}

Adapun jenis penelitian yang digunakan dalam pola komunikasi guru dalam pembelajaran anak usia dini melalui bermain ini adalah dengan deskriptif kualitatif, 1) subyek penelitian adalah anak usia dini yang terlibat langsung dalam proses pembelajaran, Penggalian informasi pada penelitian ini menggunakan metode observasi, wawancara dan dokumentasi. Metode observasi digunakan untuk mengamati proses belajar mengajar yang berlangsung dengan menerapkan pola komunikasi guru dalam pembelajaran anak usia dini melalui bermain. Pada kegiatan ini, peneliti menggunakan panduan observasi dan catatan lapangan sesuai dengan kegiatan yang diteliti. Metode wawancara pada subyek penelitian untuk mengetahui bagaimana penerapan pola komunikasi guru dalam pembelajaran anak usia dini melalui bermain. Metode Dokumentasi yakni mengumpulkan dokumen-dokumen dan analisis studi literatur. 
HASIL DAN PEMBAHASAN

Pola Komunikasi Guru dalam Pembelajaran PAUD

Pola interaksi pembelajaran merupakan terjadinya komunikasi antara guru dengan anak pada suatu lingkungan belajar dan terjadinya komunikasi sehingga guru dan peserta didik saling bertukar informasi. Menurut Djamarah (Sentosa, 2015) Pola komunikasi diartikan sebagai interaksi antara dua orang atau lebih dalam proses bertukar informasi dengan cara yang tepat sehingga informasi dapat diterima dan yang dimaksud dapat dipahami". Lebih lanjut, Sudjana (2014), menyebutkan bahwa pola komunikasi terbagi ke dalam tiga pola dalam proses interaksi guru dan peserta didik pada saat pembelajaran berlangsung, pola komunikasi itu, meliputi pola komunikasi satu arah, pola komunikasi dua arah, dan pola komunikasi banyak arah. Pola komunikasi yang dilakukan di kelas A menggunakan semua pola tersebut, yaitu guru akan menggunakan pola interaksi satu arah pada saat memulai kegiatan awal pembelajaran dan pada saat guru menyampaikan materi dimana pola ini guru lebih berperan aktif, sedangkan peserta didik pasif dan hanya mendengar. Saat pola komunikasi satu arah berlangsung seringkali respon anak didik terlihat tidak begitu memperhatikan. Anak didik terlihat kehilangan konsentrasinya saat kegiatan belajar berlangsung walaupun ada beberapa anak yang memperhatikan pelajaran yang diberikan oleh guru. Namun, sebagian anak lebih memilih bermain sendiri atau bercanda dengan temannya. Oleh karena itu, guru mencoba merangsang anak dengan hal-hal yang menyenangkan, seperti tepukan yang menggembirakan.

Menurut (Sholicha, Fatonah, \& Susilo, 2015) penggunaan pola komunikasi dua arah yaitu tipe komunikasi interpersonal, dimana anak berlaku sama sebagai guru dan saling bertukar informasi. Guru sebagai komunikator menyampaikan materi melalui berbagai metode dan media yang mendukung, murid menerima materi dan memberikan timbal balik. Timbal balik yang diberikan oleh anak bersifat verbal maupun nonverbal. Pola dua arah dilakukan guru pada saat kegiatan bercakap-cakap, eksperimen, bernyanyi, maupun tanya jawab. Pola komunikasi dua arah yang dilakukan guru Kelas A bertujuan tidak hanya guru saja yang aktif, tetapi anak-anak juga terlibat aktif. Respon anak-anak terlihat lebih tenang karena guru melakukan komunikasi tatap muka secara langsung. Guru pun juga akan mampu melihat seberapa besar anak didik mengerti dan menangkap pelajaran yang diberikan. Guru akan memanggil anak untu maju kedepan untuk melihat sejauh mana anak memahi penjelasan yang diberikan guru. Jika anak didik belum mengerti, maka guru akan menjelaskan kembali pelajaran yang sebelumnya disampaikan. Namun, beberapa anak terlihat canggung, acuh, mendengarkan atau mungkin takut saat harus melakukan komunikasi tatap muka sehingga anak lebih banyak diam atau merespon sekedarnya. Hal ini disiasati oleh guru dengan komunikasi yang lebih intensif kepada anak agar anak terbiasa dengan cara guru mengajak anak untuk bercakap-cakap, bercerita, dan bernyanyi.

Guru kelas B juga menggunakan pola komunikasi banyak arah dalam proses pembelajaran tidak hanya terjadi interaksi antara guru dan anak tetapi juga adanya interaksi antara anak ke anak sehingga suasana sekolah di kelas lebih ramai. Pada saat anak bertanya terkadang akan memberikan umpan balik kepada anak lain untuk menjawab pertanyaan temannya. Namun, hal pola yang lebih dominan dilakukan dalam proses pembelajaran d kelas yaitu guru melakukan pola komunikasi dua arah dimana guru dan anak sebagai penerima dan pemberi aksi. Berdasarkan pendapat Riyana (2014) komponen-komponen pembelajaran yang diperlukan dalam proses interaksi antara guru dan peserta didik, yaitu tujuan, materi, metode, media, dan evaluasi pembelajaran. Pada saat memulai pembelajaran guru kelas A sudah menyusun tujuan-tujuan apa saja yang harus dicapai oleh anak. Tujuan tersebut sudah ditulis oleh guru di RPPH dan tujuan-tujuan yang perlu dicapai berdasarkan kegiatan dan tema yang akan disampaikan pada hari tersebut. Penyampaian materi yang dilakukan guru kelas A ditunjukkan dengan suara yang lantang sehingga anak tidak merasa ngantuk, 
kemudian penyampaian materi disesuaikan dengan bahasa yang mudah dipahami oleh anak. Sehingga anak mudah memahami apa saja yang disampaikan oleh guru.

Guru kelas A juga menyiapkan media konkret maupun media gambar pada saat menyampaikan materi, hal ini bertujuan agar anak lebih mudah menerima dan lebih tertarik pada saat kegiatan tersebut. Adanya media yang ditunjukkan oleh guru membuat anak-anak lebih semanat untuk belajar dan memberikan kesempatan kepada anak untuk berekspresi. Metode pembelajaran yang dilakukan guru kelas A sangatlah beragam yaitu adanya metode bercakap-cakap dan tanya jawab membuat guru dan anak berbagi cerita dan pengalaman yang dimiliki. Menurut (Kinasih, Amalia, \& Priyambadha, 2018) penilaian yang dilakukan oleh guru memuat catatan mengenai segala kegiatan dan perilaku anak selama proses pembelajaran berlangsung. Kegiatan evaluasi dilakukan di akhir pembelajaran dimana guru kelas A bertanya kepada anak apa saja kegiatan yang dilakukan dalam satu hari. Guru juga melakukan evaluasi berupa penilaian apakah kegiatan hari ini sudah terlaksana dengan baik atau perlu ditingkatkan lagi di keesokan harinya.

\section{Perkembangan Bahasa (Komunikasi) Anak Melalui Permainan}

Melalui permainan, pengembangan Bahasa seperti: mampu menunjukkan sikap mandiri, mengendalikan perasaan, menunjukkan rasa percaya diri, menunjukkan sikap toleran, mengekspresikan emosi sesuai dengan keadaan, menunjukkan rasa empati mampu menghargai perbedaan orang lain, memiliki sikap gigih (tidak mudah menyerah), bangga terhadap hasil karya sendiri serta mau berbagi, menolong, mau membantu teman; menunjukkan antusiasme dalam melakukan permainan kompetitif secara positif; menaati aturan yang berlaku dalam suatu permainan; menjaga diri sendiri dari lingkungannya; dan menghargai orang lain diharapkan dapat berkembang sesuai harapan, berkomunikasi dengan guru, orangtua dan teman bahkan bekembang sangat baik. Jarangnya dilakukan permainan disebabkan oleh kurangnya lahan untuk bermain dan keterbatasan pengetahuan guru TK untuk mengembangkan permainan. Permainan yang dilakukan hanyalah permainan umum seperti ular naga, kucing dan tikus, gobag sodor dan beberapa permainan umum lainnya yang belum dikembangkan oleh guru. Pembelajaran melalui permainan yang beragam, baik outdoor maupun indoor diharapkan dapat meningkatkan minat dan antusias anak dalam mengikuti pembelajaran sekaligus meningkatkan aspek perkembangan anak. Anak dapat belajar banyak hal melalui permainan. Diharapkan pula, keterbatasan lahan tidak menjadi kendala atau hambatan bagi guru untuk menyelenggarakan pembelajaran kelompok. Oleh karena itu, berdasarkan adanya permasalahan tentang keterbatasan pengetahuan guru tentang ragam permainan untuk mengasah perkembangan Bahasa komunikasi anak, mendorong kami sebagai mahasiswa calon guru anak usia dini untuk mengembangkan panduan model permainan dan media sesuai tema yang dapat dikembangkan di TK untuk membantu memberikan gambaran tentang beberapa permainan dan media pembelajaran yang dapat diimplementasikan di PAUD dalam rangka mengoptimalkan perkembangan Bahasa komunikasi anak.

Media permainan/ media untuk bermain

Langkah pembuatan media :

1. Menggunting kardus dengan bentuk persegi

2. Siapkan gambar buah yang belum bewarna, kemudia warnai dengan pensil warna sesuai warna buah.

3. Tempelkan buah yang telah diwarnai ke kertas karton, lalu gunting sesuai bentuk buah.

4. Kemudian tempel gambar buah tersebut kardus yang telah dibentuk dan juga sesuaikan dengan bentuk buah

5. Lobangi sisi kedua ujung kiri dan kanan

6. Kemudian buatlah benang wol secukupnya (sampai bisa dikalungkan oleh anak) 


\section{Langkah Menggunakan Media}

1. Bagi anak menjadi beberapa kelompok dan tentukan nama kelompoknya

2. Kemudian mintalah anak untuk mengambil nama-nama buah yang telah dibuat berbentuk persegi di gantungkan atau di kalungkan di lehernya

3. Setelah itu anak akan dibagi nama-nama buah dan nama anak berubah menjadi nama buah tersebut. jadi semua anak harus mengingat nama temannya yang diganti dengan nama buah.

4. Lalu mereka melakukan hompimpah yang kalah akan menjadi penebak

5. Setelah itu anak yang berperan sebagai penebak akan dikekelingi oleh temannya. Dan nama buah yang dikalungkan tersebut dibuat di belakang punggung anak. Sehingga anak tidak tau nama buah tersebut

6. Kemudian anak yang berperan sebagai penebak akan terus menebak nama buah yang ada di punggungnya sampai ia berhasil menebak

Kegunaan anak bermain menggunakan permainan menebak buah-buahan dapat mengembangkan semua aspek perkembangan anak, yaitu:

1. Fisik motorik : di peroleh anak saat melakukan gerakan badan pada saat bermain menebak buah-buahan

2. Agama dan moral : anak-anak menghargai ciptaan Tuhan, mengetahui bhwa buahbuahan di ciptakan oleh Tuhan dan berdoa sebelum bermain.

3. Kognitif : diperoleh anak saat mencoba menebak dan mengingat nama buah-buahan

4. Sosial emosional : diperoleh anak saat menjalin kerjasama dan komunikasi dengan temannya. Dan tidak bermain curang

5. Bahasa : diperoleh anak saat mengucapkan nama-nama buah-buahan ketika menebak saat bermain dan anak akan menjalin komunikasi dengan teman-temannya. Kosa kata yang diperoleh anak juga akan semakin banyak.

6. Seni : diperoleh anak saat melihat warna yang bermacam-macam pada gambar buahbuahan kemudian bernyanyi saat sedang bermain.

\section{SIMPULAN}

Pola interaksi satu arah yang dilakukan guru dalam pembelajaran seperti penyampaian materi, arahan atau nasehat-nasehat yang diberikan guru. Pola interaksi dua arah yaitu kegiatan tanya jawab, bercakap-cakap, bernyanyi dalam proses pembelajaran di sekolah. Pola komunikasi banyak arah dapat ditunjukkan tidak hanya guru dan anak yang melakukan interaksi, namun antara anak dan anak juga berinteraksi, seperti pada saat anak bercerita. Pola komunikasi yang sering digunakan oleh guru yaitu pola komunikasi satu arah sehingga anak menjadi lebih pasif dan hanya mendengarkan guru.

Jenis-jenis komunikasi yang dilakukan guru adalah verbal dan non verbal dimana guru dalam berkomunikasi bertatap secara langsung dan menggunakan kata-kata sehingga memudahkan anak untuk mengerti apa yang disampaikan. Guru juga menggunakan komunikasi non verbal berupa penggunaan suara yang embut dan lantang, gerakan yang dilakukan saat menyampaikan materi, serta penggunaan isyarat pada saat berkomunikasi kepada anak.

Berdasarkan kesimpulan dari hasil analisis di atas, saran yang dapat diberikan oleh penulis berupa mengenai pola komunikasi yang digunakan oleh guru hendaknya lebih bervariasi tidak hanya pada pola komunikasi satu arah. Guru dapat mengaplikasikan pola komunikasi banyak arah sebagai acuan agar anak menjadi lebih aktif dan semangat dalam proses pembelajaran. Beragamnya pola komunikasi guru dapat membantu mencapai tujuan aspek pertumbuhan dan perkembangan anak. Komunikasi non verbal yaitu berupa suara diharapkan guru menggunakan suara yang sedikit lantang sehingga anak mudah mendengarkan apa yang disampaikan guru dan lebih aktif serta semangat dalam belajar. 


\section{DAFTAR PUSTAKA}

Fadlillah,M.,dkk.2014. "Edutainment Pendidikan Anak Usia Dini Menciptakan Pembelajaran Menarik, Kreatif, Dan Menyenangkan”. Jakarta: Prenadamedia Group.

Inopendas Jurnal Ilmiah Kependidikan, Volume 1 Nomor 1, februari 2018. Martani, Wisjnu. 2012. "Metode Stimulasi dan Perkembangan Anak Usia Dini”. Yogyakarta. Jurnal Psikologi

Mulyana, D. (2002). "Ilmu Komunikasi: Suatu Pengantar". Bandung: PT Remajan Rosdakarya.

Nurmala, R., Maulana, S., \& Prasetio, A. (2016). "Komunikasi Verbal dan Non verbal Dalam Proses Kegiatan Belajar Mengajar (Studi Kasus pada Kegiatan Belajar Mengajar di Rumah Bintang Gang Nangkasuni”, Wastukencana Bandung). EProceeding of Management, 3(1), 802-809.

Risaldy, S. (2014). "Bermain, Bercerita, dan Menyanyi". Jakarta: Luxima Metro Media.

Sentosa, A. T. (2015). "Pola Komunikasi Dalam Proses Interaksi Sosial di Pondok Pesantren Nurul Islam Samarinda. Jurnal Ilmu Komunikasi Universitas Mulawarman", 3(3), 491-503.

Sholicha, H. P., Fatonah, S., \& Susilo, E. (2015). "Pola Komunikasi Antara Guru dan Murid Dalam Menyampaikan Pendidikan Seks Bagi Anak Usia Dini". Jurnal Ilmu Komunikasi, 13(3), 224-233. 